Hal: $75-80$

\title{
PEMBELAJARAN ANALOGI UNTUK MEMBENTUK SIKAP DAN MORAL SISWA PADA KONSEP LOGIKA MATEMATIKA
}

\author{
Rizki Putri Yolanda Ritonga1), Lily Rohanita Hasibuan ${ }^{2)}$ \\ ${ }^{1,2)}$ Pendidikan Matematika, FKIP Universitas Labuhanbatu, JI. SM Raja, No.126 A, Km 3,5, Aek Tapa \\ Rantau Prapat. Indonesia \\ Email: rizkiyolanda@gmail.com, Irohanita30@gmail.com
}

\begin{abstract}
Abstrak. Permasalahan dalam penelitian ini adalah sebagian besar perilaku siswa masih belum mencerminkan sikap dan moral yang baik. Sikap dan moral di SMA Negeri 2 Bilah Hulu hanya disampaikan oleh guru mata pelajaran pendidikan kewarganegaraan dan pendidikan agama, sedangkan untuk mata pelajaran yang lainnya guru lebih berfokus pada penyampaian materi dibandingkan penanaman nilai sikap dan moral kepada siswa. Penelitian ini bertujuan untuk mendeskripsikan bentuk sikap dan moral siswa setelah diberikan pembelajaran analogi pada konsep logika matematika di Kelas XI SMA Negeri 2 Bilah Hulu. Penelitian ini merupakan penelitian kualitatif. Subjek dalam penelitian ini adalah seluruh siswa kelas XI MIA 1 SMA Negeri 2 Bilah Hulu pada semester genap Tahun Pembelajaran 2018/2019. Instrumen penelitian yang digunakan yaitu lembar observasi sikap dan moral siswa. Data dianalisis dengan menggunakan analisis deskiptif. Hasil analisis deskriptif menunjukkan persentase ratarata sikap dan moral siswa pada pertemuan I sebesar $41,55 \%$, pada pertemuan II sebesar $60,44 \%$, pada pertemuan III sebesar $77,99 \%$, dan pada pertemuan IV sebesar $85,75 \%$. Persentase sikap dan moral siswa tersebut menunjukkan adanya peningkatan pada tiap pertemuan. Dari hasil tersebut dapat disimpulkan bahwa pembelajaran analogi dapat membentuk sikap dan moral siswa.
\end{abstract}

\section{Kata Kunci : Pembelajaran Analogi, Sikap dan Moral Siswa}

\begin{abstract}
Abstrack. The problem in this study is that there are still a large number of students behaving or behaving not reflecting good attitude and moral values. The attitudes and morals of Bilah Hulu Public High School are only conveyed by subject teachers of civic education and religious education, while for other subjects the teacher focuses more on the delivery of material than planting attitude and moral values to students. This study aims to describe the form of attitudes and morals of students after being given analogy learning on mathematical logic concepts in Class XI of SMA Bilah Hulu. This research is a qualitative research. The subjects in this study were all students of class XI MIA 1 in SMA Bilah Hulu in the even semester of the Learning Year 2018/2019. The research instruments used were observation sheets of students' attitudes and morals. Data were analyzed using deskiptif analysis. The results of the descriptive analysis showed that the average percentage of attitudes and morals of students at the first meeting was $41.55 \%$, at the second meeting they were $60.44 \%$, the third meeting was $77.99 \%$, and in the IV meeting $85.75 \%$. The percentage of students' attitudes and morals shows an increase in each meeting. From these results it can be concluded that analogy learning can shape students' attitudes and morals.
\end{abstract}

Keywords: Analogy Learning, Attitudes and Moral of Students

\section{PENDAHULUAN}

Di era globalisasi saat ini para pelajar seperti kehilangan arah dan tujuan. Mereka terjebak pada lingkaran dampak globalisasi yang lebih mengedepankan sikap tidak peduli yang mengarah pada sifat anarkisme bahkan banyak masyarakat yang menganggap generasi muda sekarang ini tidak memberikan pengaruh positif sebagai seorang yang terpelajar (A.P, 2017). Sistem pendidikan kita selama ini masih lebih menitikberatkan pada penguasaan kognitif akademis, sementara afektif dan psikomotorik bukan menjadi prioritas lagi padahal nilai tersebut sangat penting dalam membentuk pribadi sang anak sehingga pada akhirnya menjadi pribadi yang miskin tata krama, sopan santun dan etika moral.

Bertolak dari fenomena tersebut maka pada dasarnya proses pendidikan bukan hanya membentuk kecerdasan atau keterampilan tertentu saja, akan tetapi membentuk dan mengembangkan sikap dan moral agar anak berprilaku sesuai dengan norma-norma yang berlaku di masyarakat seiring dengan dampak negatif dari kemajuan teknologi dan era modernnisasi, untuk itu guru sangat berperan membantu perkembangan anak secara optimal. Pendidikan sikap dan moral pada siswa biasanya hanya didapat melalui guru mata pelajaran kewarganegaraan dan pendidikan agama saja, sedangkan untuk pelajaran lain guru hanya menyampaikan materi pelajaran tanpa menanamkan nilai sikap dan moral melalui pembelajaran tersebut. Perlu ditekankan bahwa pembentukan sikap dan moral anak merupakan aspek yang tidak kalah pentingnya 


\section{Hal: $75-80$}

disamping pembentukan kemampuan intelektual dan kemampuan keterampilan. Namun, dalam proses pendidikan proses pembentukan sikap dan moral kadang masih terabaikan. Sikap dan moral hanya disampaikan oleh guru mata pelajaran pendidikan kewarganegaraan dan pendidikan agama, sedangkan untuk mata pelajaran yang lainnya guru lebih berfokus pada penyampaian materi dibandingkan penanaman nilai sikap dan moral kepada siswa.

Pendidikan mempunyai peranan yang sangat penting dalam menentukan perkembangan dan pembangunan bangsa dan negara. Kemajuan suatu bangsa bergantung pada bagaimana bangsa tersebut mengenali, menghargai, dan memanfaatkan sumber daya manusia. Dalam hal ini berkaitan erat dengan kualitas pendidikan yang diberikan kepada anggotatentang Sistem Pendidikan Nasional yang menegaskan bahwa pendidikan nasional (1) berfungsi mengembangkan kemampuan dan membentuk watak serta peradaban bangsa yang bermartabat dalam rangka mencerdaskan kehidupan bangsa, (2) bertujuan untuk berkembangnya potensi peserta didik agar menjadi manusia yang beriman dan bertakwa kepada Tuhan Yang Maha Esa, berakhlak mulia, sehat, berilmu, cakap, kreatif, mandiri, dan menjadi warga negara yang demokratis serta bertanggung jawab (Kemendiknas, 2011).

Dari hasil observasi selama melaksanakan PPL dan wawancara guru-guru di SMA Negeri 2 Bilah Hulu menunjukkan bahwa masih terdapat sebagian besar siswa bersikap atau berperilaku belum mencerminkan nilai moralitas yang baik. Masih banyak siswa dalam mengerjakan tugas dari guru melihat pekerjaan teman, siswa belum mau mengakui kesalahan, tidak meminta ijin ketika akan memasuki ruangan atau menggunakanbarang milik orang lain, tidak sopan dalam berpakaian, tidak hadir di sekolah tepat waktu, tidak tertib dalam mengukuti pelajaran serta tidak mengumpulkan tugas tepat waktu, tidak menghormati teman yang berbeda suku, tidak menghargai pendapat dan tidak memaafkan kesalahan orang lain, tidak mengerjakan tugas individu dengan baik, tidak melaksanakan piket kelas sesuai dengan jadwal dan tidak mengikuti pelajaran di sekolah dengan penuh semangat.

Berdasarkan permasalahan di atas, maka perlu ditanamkan nilai sikap dan moral di setiap pembelajaran. Saat ini ada alternatif lain dalam membentuk sikap dan moral siswa yaitu melalui konsep logika matematika pada pelajaran matematika. Pembelajaran yang sesuai untuk menyelesaikan masalah tersebut adalah dengan analogi. Analogi merupakan keserupaan cara memandang dua konsep yang berbeda konsep yang pertama adalah konsep yang dikenal dengan baik sedangkan konsep yang kedua adalah konsep yang baru atau tidak begitu dikenal.

Fokus penelitian dalam penelitian ini adalah bagaimana sikap dan moral siswa setelah diberikan pelajaran analogi pada konsep logika matematika di kelas XI MIA SMA Negeri 2 Bilah Hulu. Pembelajaran analogi yang dimaksud adalah tentang menyamakan materi matematika yang sesuai dengan sikap dan moral khususnya pada konseplogika matematika di kelas XI MIA SMA Negeri 2 Bilah Hulu.

Penelitian ini bertujuan untuk mendeskripsikan bentuk sikap dan moral siswa setelah diberikan pembelajaran analogi pada konsep logika matematika di Kelas XI SMA Negeri 2 Bilah Hulu.

\section{Sikap dan Moral}

Sikap merupakan tingkah laku atau reaksi yang timbul dengan cara tertentu terhadap seseorang atau suatu peristiwa, baik itu secara positif maupun negatif. Sikap terdiri dari beberapa tingkatan anatara lain : (1) Menerima stimulus yang diberikan, (2) Merespon, (3) Menghargai, dan (4) Bertanggungjawab. Dari pemaparan diatas dapat dilihat bahwa tingkatan paling tinggi dalam sikap ialah tanggungjawab.

Menurut Fishbein (1985) dalam (Yuningsih, 2014) Sikap ialah kecenderungan emosional untuk merespons secara konsisten suatu objek. Sikap merupakan variabel yang mendasari, mendireksi, dan mempengaruhi perilaku. Sikap diekspresikan ke dalam kata-kata/tindakan hasil reaksi terhadap objek, baik orang, peristiwa, situasi dan lain sebagainya. Sedangkan sesuai dengan konsep Chaplin (1981) dalam "Dictionary of Psychology" menyamakan sikap yaitu dengan pendirian. Menurutnya Sikap yaitu kecenderungan yang relatif stabil dan berlangsung terus-menerus untuk bertingkah laku/bereaksi dengan cara tertentu terhadap orang/peristiwa, baik secara positif maupun negatif.

Moral merupakan kebiasaan yang berhubungan dengan akhlak, tingkah laku, dan karakter seseorang dalam berperilaku dengan mengikuti apa kata hati mereka, baik itu buruk maupun baik. Namun, baik dan benar menurut seseorang belum tentu baik dan benar pula menurut orang yang lain.

Istilah Moral berasal dari bahasa Latin. Bentuk tunggal kata moral yaitu mos sedangkan bentuk jamaknya yaitu mores yang masing-masing memiliki arti yang sama yaitu kebiasaan atau adat. Moralitas berfokus pada perilaku manusia yang benar dan salah, sehingga moralitas berhubungan dengan pertanyaan bagaimana seseorang bertindak terhadap orang lain. Dengan kata lain, moralitas adalah tekad untuk mengikuti apa yang ada dalam hati manusia dan disadari sebagai kewajiban mutlak (Aranta, 2014). 


\section{Hal: $75-80$}

Tabel 1. Indikator Sikap dan Moral

\begin{tabular}{|l|l|}
\hline \multicolumn{1}{|c|}{ Variabel } & \multicolumn{1}{c|}{ Indikator } \\
\hline \multirow{4}{*}{ Sikap dan Moral } & 1) Jujur \\
\cline { 2 - 2 } & 2) Disiplin \\
\cline { 2 - 2 } & 3) Tanggungjawab \\
\hline & 4) Toleransi \\
\hline & 5) Percaya Diri \\
\hline
\end{tabular}

Keuntungan analogi dalam pengajaran menurut Destiawaty (2012) antara lain:

1. Dapat memudahkan siswa dalam memperoleh pengetahuan baru dengan cara mengaitkan atau membandingkan pengetahuan analogi yang dimiliki siswa.

2. Pengaitan tersebut akan membantu mengintegrasikan struktur-struktur pengetahuan yang terpisah agar terorganisasi menjadi struktur kognitif yang lebih utuh. Dengan organisasi yang lebih utuh akan mempermudah proses pengungkapan kembali pengetahuan baru.

3. Dapat dimanfaatkan dalam menanggulangi salah konsep.

Untuk menarik atau memperoleh sebuah analogi memerlukan 6 tahapan yang dilakukan oleh pengajar. 6 tahapan tersebut menurut Khotimah, dkk (2009), yaitu:

1. Konsep target.

2. Mereview atau mengulas lengkap konsep analog.

3. Mengidentifikasi atau mencari fitur-fitur atau atribut-atribut relevan antara target dan analog.

4. Memetakan keserupaan antara konsep-konsep analog dan target.

5. Mengidentifikasi atau mencari keadaan pengecualian yang manaanalogi tersebut tidak bekerja.

6. Mengambil kesimpulan-kesimpulan tentang konsep-konsep target.

\section{Pembelajaran Analogi}

Definisi analogi menurut pendapat Brian dalam (Anggraini, 2016) analogi adalah bentuk penalaran dengan mempersamakan dua hal yang berlainan. Kedua hal dibandingkan untuk dicari persamaannya. Analogi dilakukan dengan mempersamakan kedua hal yang sebenarnya berlainan.

$\mathrm{Hal}$ ini sesuai dengan pernyataan dalam acehrecoveryforum yang menyatakan bahwa "Analogi merupakan perbandingan antara dua domain, yaitu domain analogi dan domain target. Perbandingan tersebut merupakan usaha untuk membantu proses pemahaman siswa terhadap pengetahuan baru, sehingga proses belajar menjadi lebih bermakna. Semakin dekat kemiripan analogi dan target, maka siswa akan semakin mudah memahami pengetahuan baru dan akan dapat terhindar dari kesalahan konsep."

Berdasarkan pernyataan dalam acehrecoveryforum, pembelajaran dengan membandingkan antara kedua domain analogi dan target dapat menciptakan pembelajaran bermakna bagi siswa. Apabila perbandingan antara analog dengan target semakin banyak kemiripannya maka siswa akan semakin mudah memahami pengetahuan baru. Sedangkan analogi konten adalah menganalogikan suatu konsep dari konsep sebelumnya yang sudah dipahami oleh siswa.

\section{METODE PENELITIAN}

Jenis penelitian ini adalah penelitian kualitatif. Penelitian ini dilaksanakan di SMA Negeri 2 Bilah Hulu. Waktu penelitian adalah pada semester genap tahun pembelajaran 2018/2019 tepatnya tanggal 25 April sampai 03 Mei 2019. Subjek penelitian dalam penelitian ini adalah seluruh siswa kelas XI MIA 1 SMA Negeri 2 Bilah Hulu pada semester genap Tahun Pembelajaran 2018/2019.

Instrumen penelitian yang digunakan untuk sikap dan moral siswa adalah lembar observasi sikap dan moral siswa. Analisis data dalam penelitian ini dilakukan dengan teknik analisis deskriptif. 


\section{Hal: $75-80$}

\section{HASIL DAN PEMBAHASAN}

A. Persentase Sikap dan Moral Siswa pada setiap Indikator.

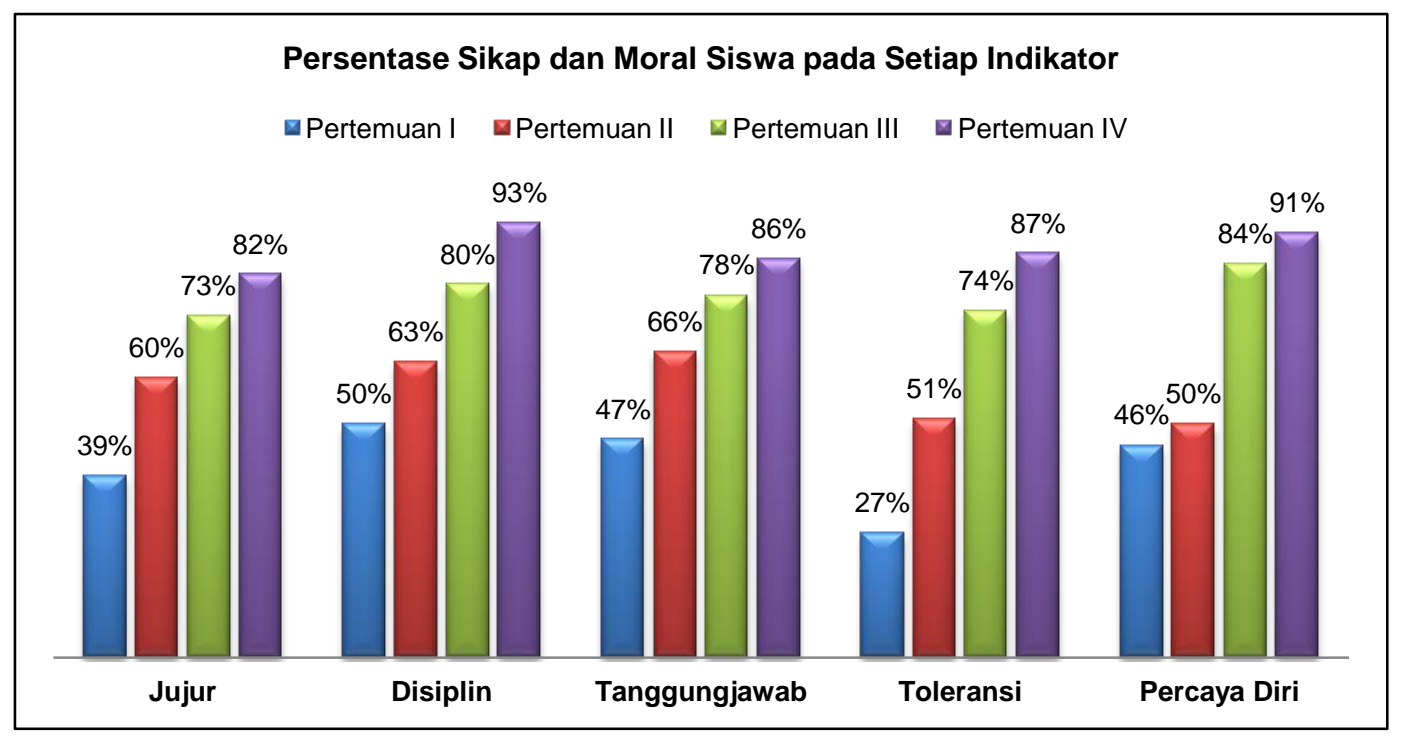

Gambar 1. Persentase Sikap dan Moral Siswa pada setiap Indikator

Berdasarkan gambar diagram batang persentase sikap dan moral siswa pada setiap indikator dari pertemuan I sampai pertemuan IV dapat dilihat bahwa persentase setiap indikator selalu mengalami peningkatan. Persentase indikator terendah pada pertemuan I diduduki oleh indikator toleransi dan persentase tertinggi diduduki oleh indikator tanggungjawab. Pada pertemuan IV indikator yang memperoleh persentase terendah adalah jujur dan persentase tertinggi adalah indikator disiplin.

Penelitian yang dilakukan oleh peneliti adalah tentang pembelajaran analogi untuk membentuk sikap dan moral siswa pada konsep logika matematika yang didukung dengan instrumen lembar observasi bentuk sikap dan moral siswa. Berdasarkan hasil observasi sikap dan moral siswa pada pertemuan I, indikator jujur memperoleh rata-rata persentase yaitu $38,88 \%$ atau kategori sangat rendah. Hal ini disebabkan oleh kebiasan buruk siswa yang masih melekat di dalam diri misalnya siswa masih cenderung mencontek ketika ulangan dengan teman sebangkunya, terbiasa berbohong untuk menutupi kesalahan temannya dan tidak bisa menerima bahwa mereka memiliki kekurangan di dalam diri mereka. Pada pertemuan II, rata-rata persentase indikator jujur bertambah menjadi 59,99\% atau kategori sedang. Pada pertemuan II sudah mulai terlihat bentuk sikap dan moral siswa pada indikator jujur. Rata-rata persentase sikap dan moral siswa pada indikator jujur pada pertemuan III kembali mengalami kemajuan yaitu dengan persentase $73,33 \%$ atau kategori tinggi. Pada pertemuan IV rata-rata persentase sikap dan moral siswa pada indikator jujur meningkat menjadi 82,11 atau kategori tinggi. Pada pertemuan IV dapat dikatakan bahwa sikap dan moral siswa sudah terbentuk yaitu pada indikator jujur. Sesuai dengan penelitian relevan yang telah dilakukan oleh Permatasari. I, Hamid. A. S, dan Setia. A. B (2014) yang berjudul "Implementasi Model Pembelajaran Pemaknaan Mata Pelajarn IPA dalam Kurikulum 2013" menunjukkan bahwa model pembelajaran pemaknaan merupakan model pembelajaran inovatif melalui contoh teladan karakter jujur, tanggungjawab, dan disiplin mendapatkan nilai sangat baik dan baik.

Sikap dan moral siswa pada indikator disiplin di pertemuan I memperoleh rata-rata persentase 49,99\% atau kategori rendah. Siswa sudah terbiasa datang terlambat karena meskipun mereka terlambat, mereka tetap bisa mengikuti pembelajaran pada les pertama karena sekolah tempat peneliti melakukan penelitian masih belum memiliki pagar yang dapat membuat siswa bisa masuk ke sekolah tanpa harus diketahui oleh guru. Pada pertemuan II siswa mulai datang tepat waktu meskipun belum seluruhnya, diketahui dengan ratarata persentase pada indikator disiplin sebesar $63,33 \%$ atau kategori sedang. Rata-rata persentase pada pertemuan III kembali mengalami peningkatan yaitu sebesar $79,99 \%$ atau kategori tinggi. Pada pertemuan IV rata-rata persentase indikator disiplin bertambah menjadi $93,33 \%$ atau kategori sangat tinggi. Pada pertemuan IV sudah terbentuk sikap dan moral siswa pada indikator disiplin meskipun belum seluruh siswa memunculkan dimensi dari indikator disiplin. Beberapa siswa masih datang terlambat dikarenakan transportasi yang mereka gunakan adalah bus. Sesuai dengan penelitian relevan yang telah dilakukan oleh Ramdhayani E, Ibrahim M, dan Madlazim (2015) yang berjudul "Pembelajaran Sikap Melalui Analogi Dalam Mengajarkan Biologi”. Hasil penelitian yang dilakukan oleh Ramdhayani E, Ibrahim M, dan Madlazim 


\section{Hal: $75-80$}

menunjukkan bahwa analogi dapat digunakan untuk membelajarkan sikap gigih, disiplin tolong menolong dan rela berkorban.

Berdasarkan hasil observasi sikap dan moral siswa pada pertemuan I, indikator tanggungjawab memperoleh rata-rata pesentase $46,66 \%$ atau kategori rendah. Pada pertemuan I hampir setengah dari 30 orang siswa masih belum menunjukkan indikator tanggungjawab yaitu pada dimensi menerima risiko dari tindakan yang dilakukan. Masih banyak siswa yang tidak terima jika sepatu yang mereka gunakan disita oleh guru BK karena tidak berwarna hitam seluruhnya. Pada pertemuan II rata-rata persentase indikator tanggungjawab adalah $65,55 \%$ atau kategori sedang. Pada pertemuan II belum tampak bahwa sikap dan moral siswa terbentuk pada indikator tanggungjawab sebab siswa masih belum memunculkan dimensi mengakui dan meminta maaf atas kesalahan yang dilakukan, siswa masih cenderung marah jika sepatu mereka disita oleh guru BK sekolah. Rata-rata persentase indikator tanggungjawab pada pertemuan III adalah $77,77 \%$ atau kategori tinggi, sudah mulai tampak bentuk sikap dan moral siswa pada indikator tanggungjawab. Pada petemuan IV rata-rata persentase adalah $85,55 \%$ atau kategori tinggi. Pada pertemuan ini dapat dikatakan bahwa sikap dan moral siswa pada indikator tanggungjawab sudah terbentuk karena sudah hampir seluruh siswa memunculkan dimensi mengakui dan meminta maaf atas kesalahan yang dilakukan.

Hasil observasi sikap dan moral siswa pada pertemuan I indikator toleransi rata-rata persentasenya adalah $26,66 \%$ atau kategori sangat rendah. Indikator toleransi adalah persentase indikator paling rendah pada pertemuan I. Pada indikator toleransi yaitu dimensi dapat menerima kekurangan memaafkan kesalahn orang lain, hanya 7 siswa yang memunculkan dimensi tersebut tercatat dari seluruh jumlah siswa adalah dari 30 orang siswa. Pada pertemuan II rata-rata persentase indikator toleransi adalah $51,11 \%$ atau kategori rendah yang berarti bahwa bentuk sikap dan moral siswa pada indikator toleransi belum tampak muncul. Rata-rata persentase indikator toleransi pada pertemuan III adalah $74,44 \%$ atau kategori tinggi. Pada pertemuan III mulai muncul indikator toleransi terutama dimensi mau bekerja sama dengan siapapun. Pada pertemuaan IV rata-rata persentase sikap dan moral siswa pada indikator toleransi adalah $86,66 \%$ atau kategori sangat tinggi. Siswa hampir sudah seluruhnya memunculkan indikator toleransi terutama dimensi mau bekerja sama dengan siapapun, dari 30 orang siswa terdapat 27 orang siswa yang memunculkan dimensi mau bekerja sama dengan siapapun. Pada pertemuan IV dapat dikatakan bahwa sikap dan moral siswa sudah terbentuk pada indikator toleransi.

Data yang diperoleh dari hasil observasi sikap dan moral siswa pada indikator percaya diri adalah $45,55 \%$ atau kategori rendah pada pertemuan I. Pertemuan I peneliti menemukan masih banyak siswa yang belum berani berpendapat, bertanya, atau menjawab pertanyaan yang dimana tersebut adalah indikator dari percaya diri dimensi berani berpendapat, bertanya, atau menjawab pertanyaan. Pada pertemuan II, rata-rata persentase sikap dan moral siswa pada indikator percaya diri adalah $62,22 \%$ atau kategori sedang. Pada pertemuan II peneliti melihat jumlah siswa yang memunculkan dimensi berani berpendapat, bertanya, atau menjawab pertanyaan adalah 20 orang dari 30 siswa. Rata-rata persentas indikator percaya diri pada pertemuan III adalah $84,44 \%$ atau kategori tinggi, peneliti menemukan hampir seluruh siswa memunculkan indikator percaya diri pada dimensi berani berpendapat, bertanya, atau menjawab pertanyaan terbukti dari 30 orang siswa terdapat 27 siswa yang memunculkan dimensi berani berpendapat, bertanya, atau menjawab pertanyaan. butir 2.1 yaitu siswa datang tepat waktu diperoleh bahwa frekuensi siswa yang datang tepat waktu adalah 13 orang siswa atau sebesar 43,33\% kategori rendah pada pertemuan I. Pada pertemuan II frekuensi siswa yang datang tepat waktu adalah 15 orang siswa atau sebesar $50 \%$ kategori rendah. Pada pertemuan III siswa sudah mulai datang tepat waktu dapat dilihat dari peningkatan yang terjadi yaitu 24 orang siswa atau sebesar $80 \%$ kategori tinggi. Frekuensi siswa yang datang tepat waktu kembali mengalami peningkatan pada pertemuan IV yaitu sebanyak 28 orang siswa atau sebesar 93,33\% kategori sangat tinggi. Hal ini selaras dengan penelitian yang dilakukan oleh Pertiwiningrum yang menunjukkan bahwa untuk mengubah karakter siswa menjadi lebih positif dengan melatihkan sensitivitas moral menggunakan model pembelajaran pemaknaan terdapat 5 belahan yaitu sikap tanggung jawab, peduli sosial, kemampuan bertanya dan berpendapat dan tindakan moral (Agustina Pertiwiningrum, 2013). Hal ini juga selaras dengan perubahan karakter siswa yang semakin membaik baik pada sikap maupun moral (Safitri, The Character Education Through Analogy Learning Implementation on Vector Concepts, 2018).

Hal ini berarti pembelajaran analogi memiliki nilai efektifitas yang tinggi untuk membentuk sikap dan moral siswa. Dengan demikian, terbukti bahwa "Pembelajaran Analogi untuk Membentuk Sikap dan Moral Siswa pada Konsep Logika Matematika Di Kelas XI SMA Negeri 2 Bilah Hulu Tahun Pembelajaran 2018/2019. Hal ini selaras dengan hasil penelitian yang telah dilakukan, yakni pembelajaran analogi mampu meningkatkan semangat belajar siswa (Safitri, PEMBELAJARAN ANALOGI PADA KONSEP VEKTOR UNTUK MEMBENTUK SIKAP DAN MORAL SISWA KELAS X SMA NEGERI 1 RANTAU UTARA, 2018). 


\section{Hal:75-80}

\section{SIMPULAN}

Berdasarkan hasil analisis data dan pembahasan pada bab sebelumnya, maka dapat diambil kesimpulan sebagai berikut:

> Pembelajaran analogi dapat membentuk sikap dan moral yaitu jujur, dapat dilihat pada dimensi siswa tidak menyontek dalam mengerjakan ujian/ulangan, membuat laporan berdasarkan informasi apa adanya, dan mengakui kesalahan atau kekurangan yang dimiliki.

$>$ Pembelajaran analogi dapat membentuk sikap dan moral yaitu disiplin, dapat dilihat pada dimensi siswa melalui siswa datang tepat waktu, patuh pada tata tertib atau aturan bersama/sekolah, dan mengerjakan/mengumpulkan tugas sesuai dengan waktu yang ditentukan.

$>$ Pembelajaran analogi dapat membentuk sikap dan moral yaitu tanggungjawab, dapat dilihat pada dimensi siswa melalui siswa menerima risiko dari tindakan yang dilakukan, mengakui dan meminta maaf atas kesalahan yang dilakukan, dan menepati janji.

> Pembelajaran analogi dapat membentuk sikap dan moral yaitu toleransi, dapat dilihat pada dimensi siswa melalui siswa dapat menerima kekurangan dan memaafkan kesalahan orang lain, mau bekerjasama dengan siapapun, dan tidak memaksakan pendapat pada orang lain.

$>$ Pembelajaran analogi dapat membentuk sikap dan moral yaitu percaya diri, dapat dilihat pada dimensi siswa melalui siswa berpendapat atau melakukan kegiatan tanpa ragu-ragu, tidak mudah putus asa, dan berani berpendapat, bertanya, atau menjawab pertanyaan.

\section{UCAPAN TERIMAKASIH}

Penulis mengucapkan terimakasih kepada segenap tim Pengelola Jurnal Anargya yang telah memberikan kesempatan kepada penulis untuk mempublikasikan karya ilmiahnya.

\section{DAFTAR PUSTAKA}

A.P, D. (2017). Pengaruh Prestasil Belajar Pendidikan Kewarganegaraan Terhadap Moralitas Siswa SMP Negeri 2 Patuk Gunung Kidul. Yogyakarta: Universitas Negeri Yogyakarta.

Agustina Pertiwiningrum, M. I. (2013). Implementasi Perangkat Pembelajaran Berkarakter Berorientasi Model Pembelajaran Pemaknaan Untuk Melatihkan Sikap Moral Siswa. Jurnal Penelitian Pendidikan Sains (JPPS), 240-249.

Anggraini, P. R. (2016). Pengaruh Penggunaan Buku Siswa Berbasis Analogi Konten Terhadap Minat Dan Hasil Belajar Siswa Pada Materi Dinamika Benda Tegar. Bandar Lampung: Universitas Lampung.

Aranta, P. Z. (2014). Pengaruh Moralitas Aparat dan Asimetri Informasi Terhadap Kecenderungan Kecurangan Akuntansi (Studi Empiris Pemerintah Kota Sawahlunto). Padang: Universitas Negeri Padang.

Safitri, I. (2018). PEMBELAJARAN ANALOGI PADA KONSEP VEKTOR UNTUK MEMBENTUK SIKAP DAN MORAL SISWA KELAS X SMA NEGERI 1 RANTAU UTARA. SIMPOSIUM FISIKA NASIONAL(SFN$X X X I)$ (hal. 240-249). Medan: Universitas Negeri Medan.

Safitri, I. (2018). The Character Education Through Analogy Learning Implementation on Vector Concepts. Jurnal Penelitian dan Pengembangan Pendidikan Fisika, 75-82.

Yuningsih. (2014). Menguatkan Kembali Pendidikan Keagamaan Dan Moral Anak Didik. Jurnal ISTEK, 199216. 